\title{
UNE NOUVElLE MÉTHOdE dE DÉTERMinAtion DE LA DIRECTION DU COURANT DANS LES RIVIËRES, DANS LES CANAUX ET SUR LEURS MODËLES
}

\section{A NEW METHOD OF DERTERMINING DIRECTION OF FLOW IN RIVERS AND CANALS AND ON THEIR MODELS}

By

Dr. Harbans Lall Uppal, M.Sc., Ph.D.

Hydraulic Research Station Malakpur (Pathankot). INDIA.

Il est très important d'être renseigné sur la direction du courant dans les rivières et canaux, tout particulièrement au voisinage des installations hydrauliques ou hydroélectriques. Une concentration de courant, la formation de vortex, les tourbillons, sont quelques-uns des phénomènes indésirables dont l'ingénieur d'irrigation préfère éviter la présence sur ses ouvrages. D'autre part, on recherchera toujours une répartition convenable du courant à l'amont des ouvrages de prise en tête d'un canal, si l'on veut réduire au minimum la quantité des matériaux pénétrant dans les canaux ou dans les ouvrages d'amenée.

Dans le canal principal aussi bien que dans les canaux secondaires, il est très utile de connaître la disposition des lignes de courant, au niveau des prises en particulier, si l'on veut assurer une répartition convenable du débit et des matériaux charriés entre ces diverses artères.

Dans la méthode adoptée autrefois au Punjab, on utilisait un détecteur de direction qui consistait en un long tube entourant une tige liée à sa partie inférieure à une palette et, à sa partie supérieure, à un cadran de lecture. La lecture de ce cadran permettait de déterminer la direction du courant.

Ce résultat devait néanmoins être corrigé pour tenir compte des positions relatives du bateau et de l'appareil. Les fig. 1 et 2 représentent un
A knowledge of the direction of flow in rivers and canals especially in the vicinity of a hydraulic or hydro-electric structure is very essential. Concentration of flow, swirl formation, eddies are some of the undesirable features which the Irrigation Engineer likes to avoid during his vark. On the other hand, proper curvature of flow upstream of the canal head regulators is very much desired to be maintained for minimum silt entry into the canals or power channels. In the main line of the canals, as well as in the distributaries, knowledge of the current directions, particularly at the off-takes is very helpful for the proper regulations of discharge and silt between the main line and the off-take channels.

The method adopted in the Punjab in the past has been to use a current direction finder which consisted of a long pipe enclosing a rod connected at the bottom to a blade and at the top to a dial. From the dial reading the direction of blade could be determined. Correction had, however, to be made in the readings thus obtained for the position of the boat with respect to the current direction finder. Figs, 1 and 2 show a plot of the current directions taken with this method at Sagar and Buchiana regulators on the 
- DIAGRAM SHOWING DIRECTION OF FLOW OF CURRENT ABOVE SAGAR REGULATOR SCHEMA DONNANT LES CARACTERISTIQUES DU COURANT EN AMONT DE L'OUVRAGE DE PRISE DE SAGAR

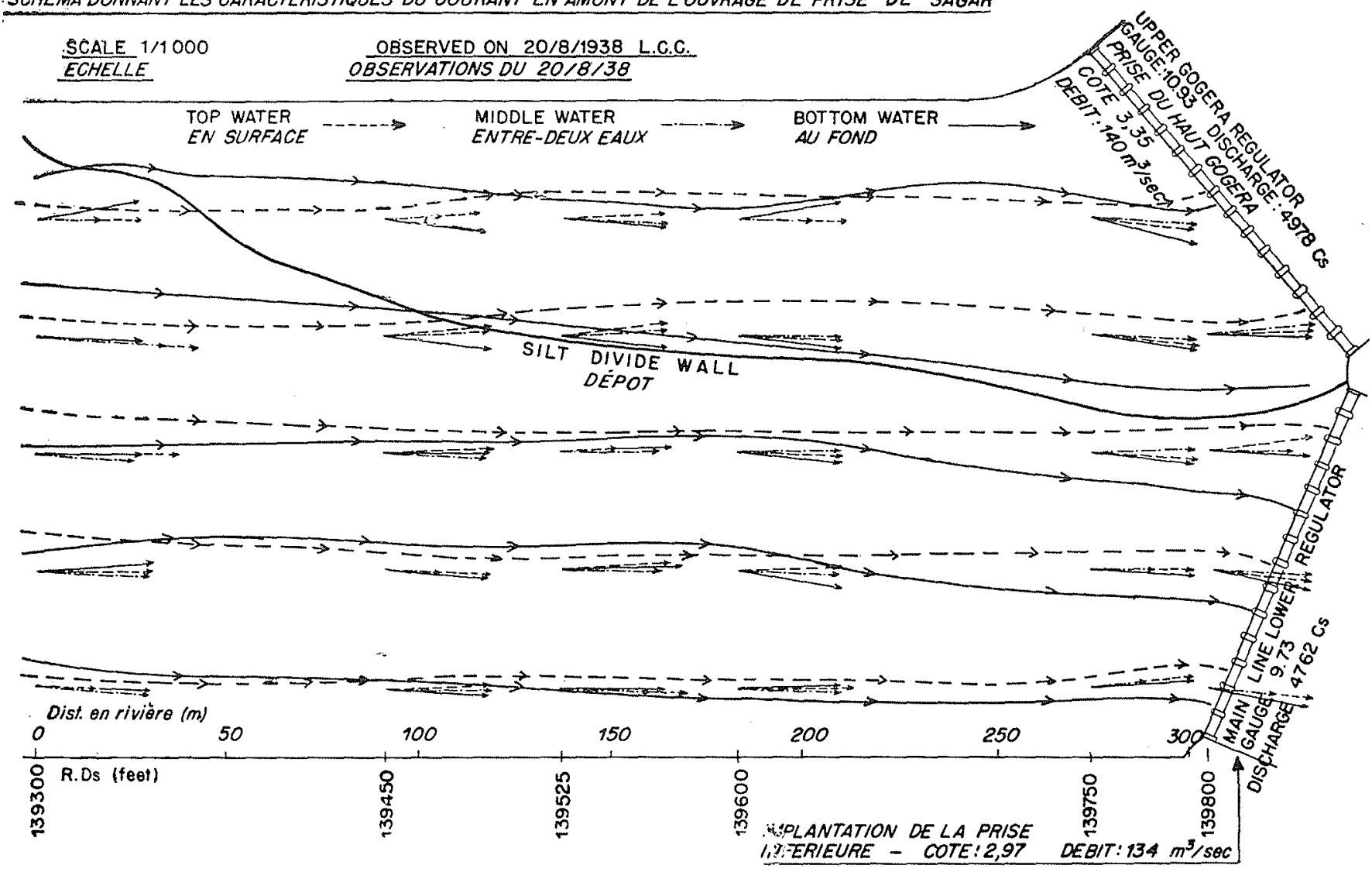

fig. 1

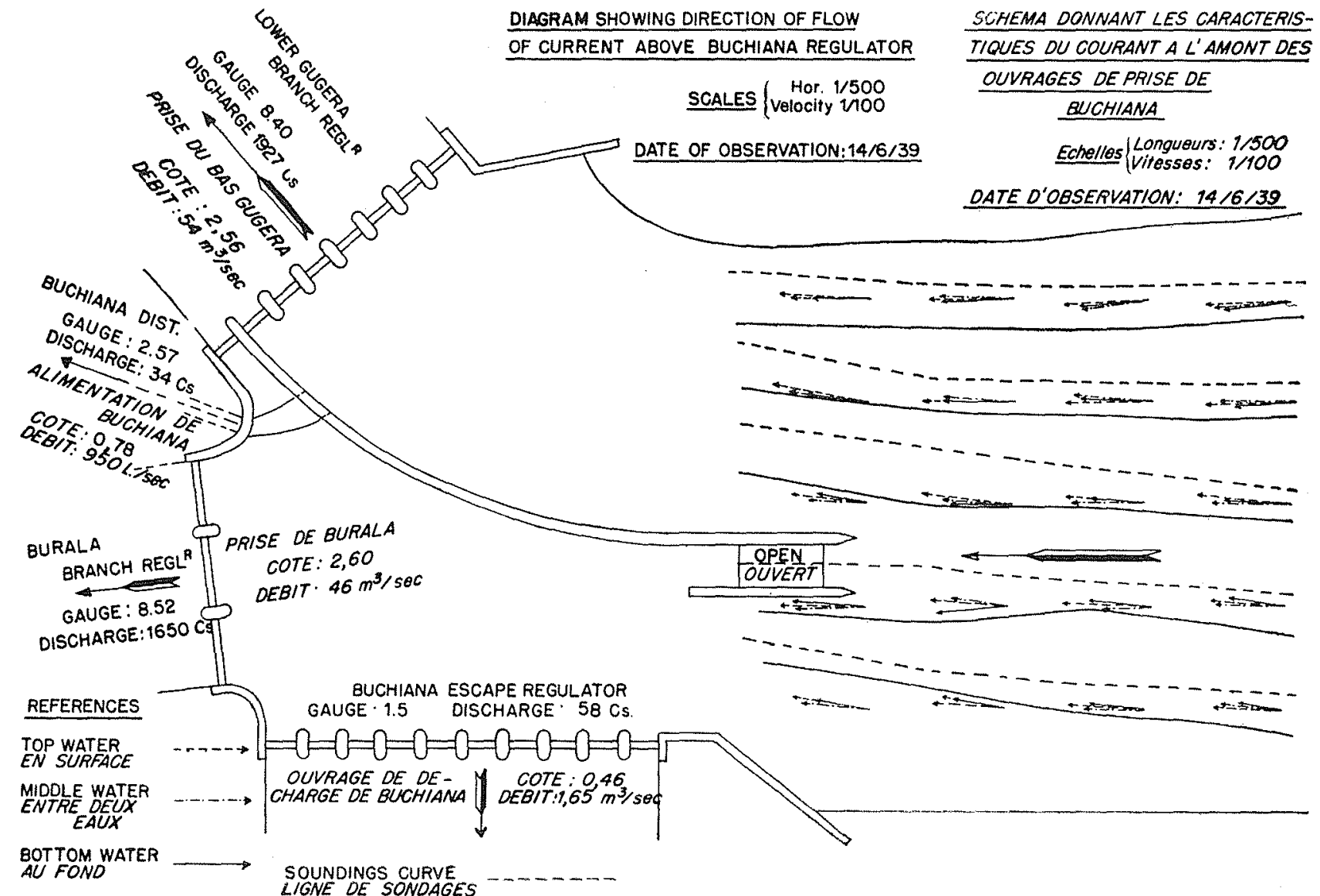




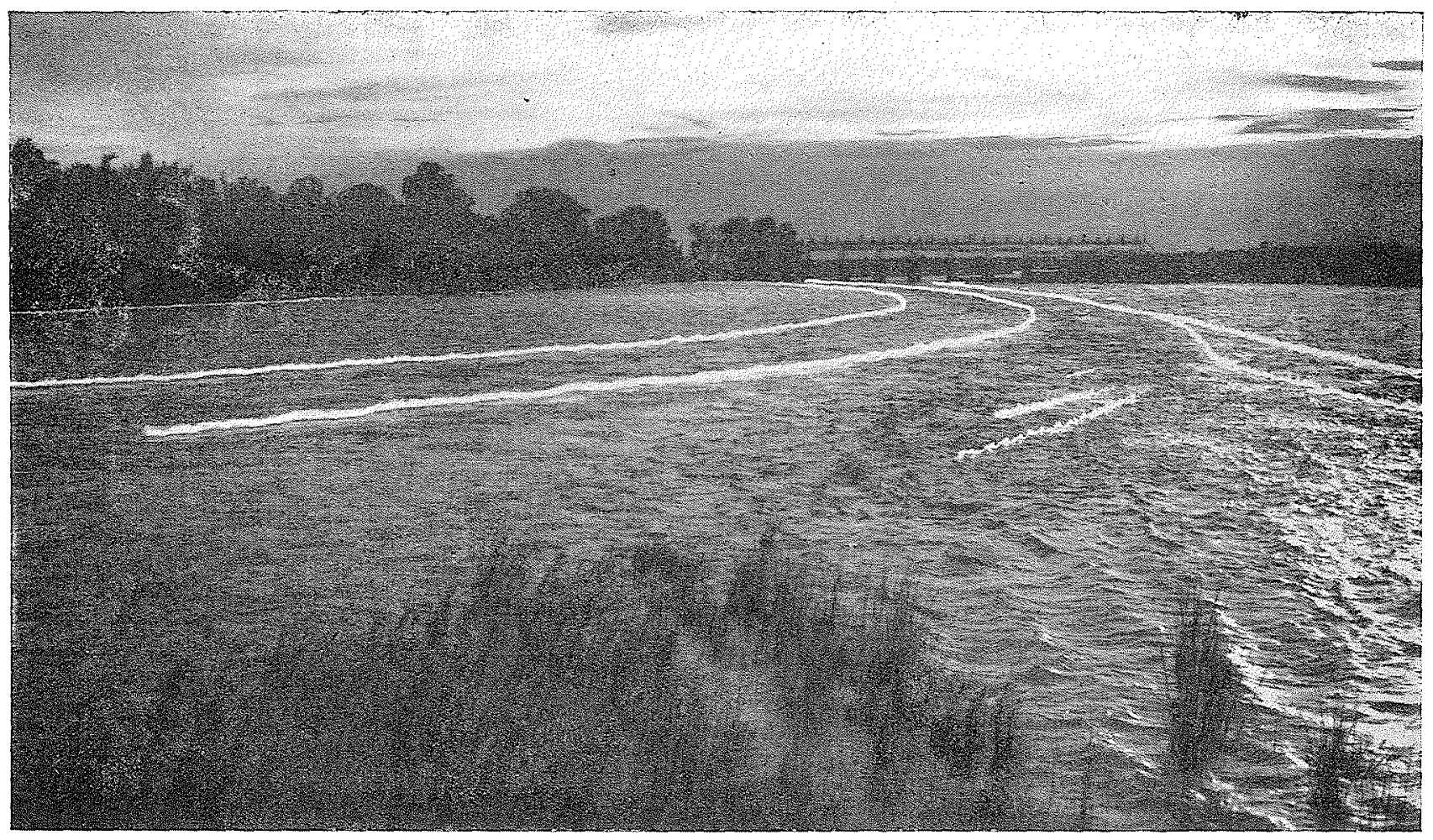

fig. 3.1

Current directions in River Ravi above Madhopur Pocket observed at end of July, 1940.

Directions du courant dans la Ravi à l'amont de la retenue de Madhopur, fin juillet 1940.

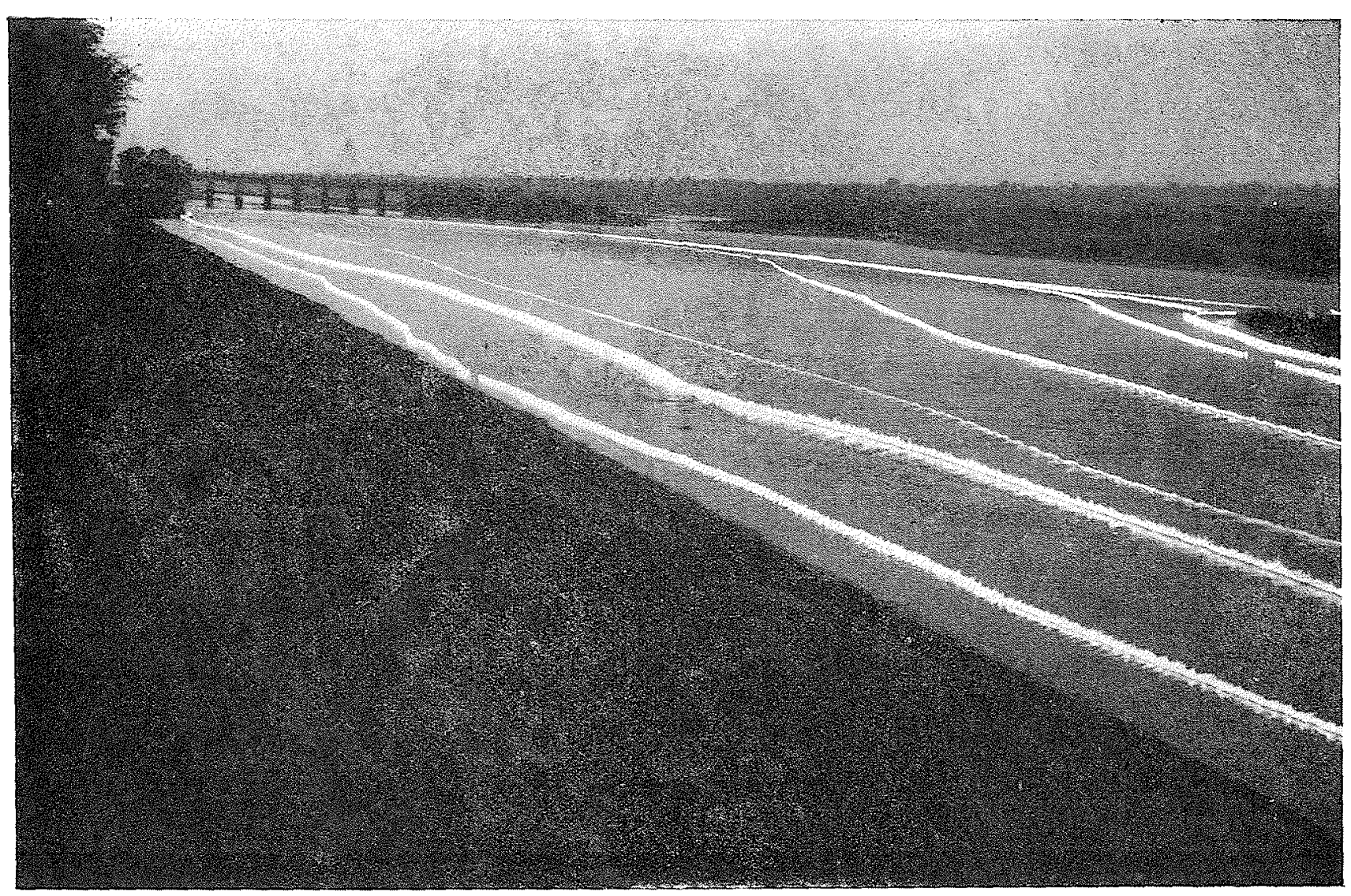

fig. $3 B$

Madhopur Headworks.

Current directions observed on 29.8.40. River discharge: $6840 \mathrm{cu}$. sec.

Ouvrages de prise de Madhopur.

Directions du courant le 29-8-40. Débit de la rivière: $190 \mathrm{~m}^{3 / \mathrm{sec}}$. 
relevé de lignes de courants exécuté suivant cette méthode, près des ouvrages régulateurs de Sagar et de Buchiana dans le Lower Chenab Canal System. Cette méthode, qui n'est pas très commode, manque de précision.

Une nouvelle méthode a été mise au point: essentiellement photographique, elle permet d'éliminer toute erreur personnelle. Le procédé adopté est le suivant :

Pendant la journée, on prend une photographie de la portion de la rivière ou du canal à l'étude, avec les ouvrages hydrauliques ou hydroélectriques. La plaque exposée est laissée dans l'appareil que l'on ne touche pas jusqu'au soir. La nuit, après avoir ouvert l'obturateur, des flotteurs lumineux sont mis à l'eau dans la rivière à l'amont de l'appareil. Cette opération est réalisée depuis un bateau, mais si le courant est trop rapide et ne le permet pas, les flotteurs sont disposés dans la rivière à l'aide d'un canot spécial.

Les flotteurs sont constitués d'une plaque de base en bois de $150 \times 150 \mathrm{~mm}$., munie au centre d'un doigt de $25 \mathrm{~mm}$. de diamètre et de $1 \mathrm{~cm}$. de long.

Des déchets de coton sont enroulés autour de ce doigt. Le flotteur est allumé juste avant sa mise à l'eau. Un certain nombre de flotteurs de ce genre sont lancés dans le courant à partir de cing ou six points différents. Lorsque le dernier flotteur est parvenu à destination, l'obturateur est fermé et l'appareil enlevé. Les trajectoires des flotteurs se traduisent sur le cliché par des lignes blanches.

Cette méthode a été mise en œuvre pour déterminer les directions du courant en plusieurs stations importantes des rivières du Punjab: par exemple :

$1^{\circ}$ La Sutlej à l'amont des ouvrages de prise du Suleimanke.

$2^{\circ}$ La Beas au niveau des épis revêtus.

$3^{\circ}$ La Ravi à l'amont des ouvrages de prise de Madhopur.

$4^{\circ}$ La Sutlej à l'amont des ouvrages de prise de Rupar.

$5^{\circ}$ La Jumna à l'amont des ouvrages de prise de Tajewala.

La fig. 3 (A à $G$ ) montre, pour différents mois, l'allure des lignes de courant sur la Ravi à Madhopur. On put déduire de ces photographies un certain nombre d'observations précieuses concer-
Lower Chenab Canal system. This method, besides being laborious, is not very accurate.

A new method has been developed. The method is essentially a photographic one. The personal error of the observer does not enter. The procedure adopted is as follows. A photograph of the river or of the canal of the reach under examination with hydraulic or hydroelectric structures is taken in the day time. The exposed plate is not removed from the camera, which is kept undisturbed until the evening. In the night the shutter of the camera is opened and lighted floats are introduced into the river upstream of the camera with the help of a boat. Where the velocity of flow is of such a high order that a boat cannot be used, the floats are dropped into the river with the help of a skin.

The floats consist of a wooden base plate $6^{\prime \prime} \times 6^{\prime \prime}$ and one inch thick with a $1^{\prime \prime}$ diameter and $4^{\prime \prime}$ long peg in the centre. Waste cotton soaked in a mixture of vegetable and kerosine oil is wrapped round the peg. The float is lighted just before introducing into the river. A number of such floats are dropped from five or six different points in the stream. After the last float has reached the destination, the shutter is closed and the camera is removed. The paths of the floats come out in white lines on the photograph. This method was used to obtain

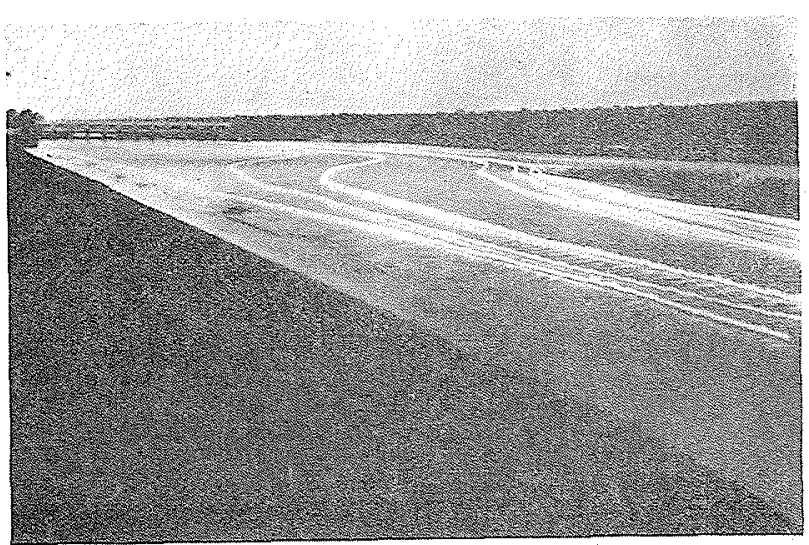

fig. $3 \mathrm{C}$

Current directions in River Ravi, Madhopur, September 1940. Direction du courant dans la Ravi, Madhopur, septembre 1940. 


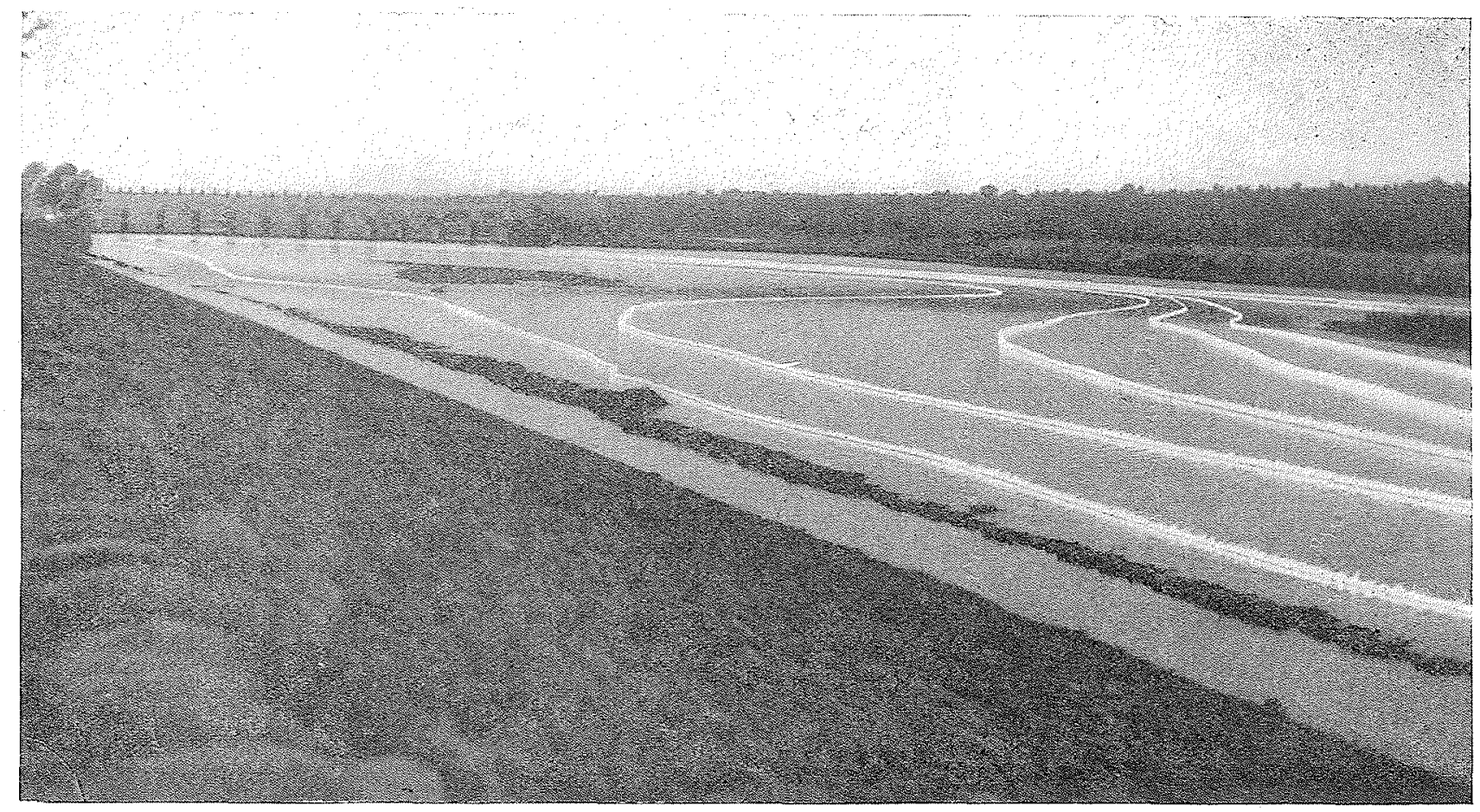

fig. $3 D$

Current directions in River Ravi above Madhopur Pocket observed at end of October, 1940.

Directions du courant dans la Ravi à l'amont de la retenue de Madhopur, fin octobre 1940.

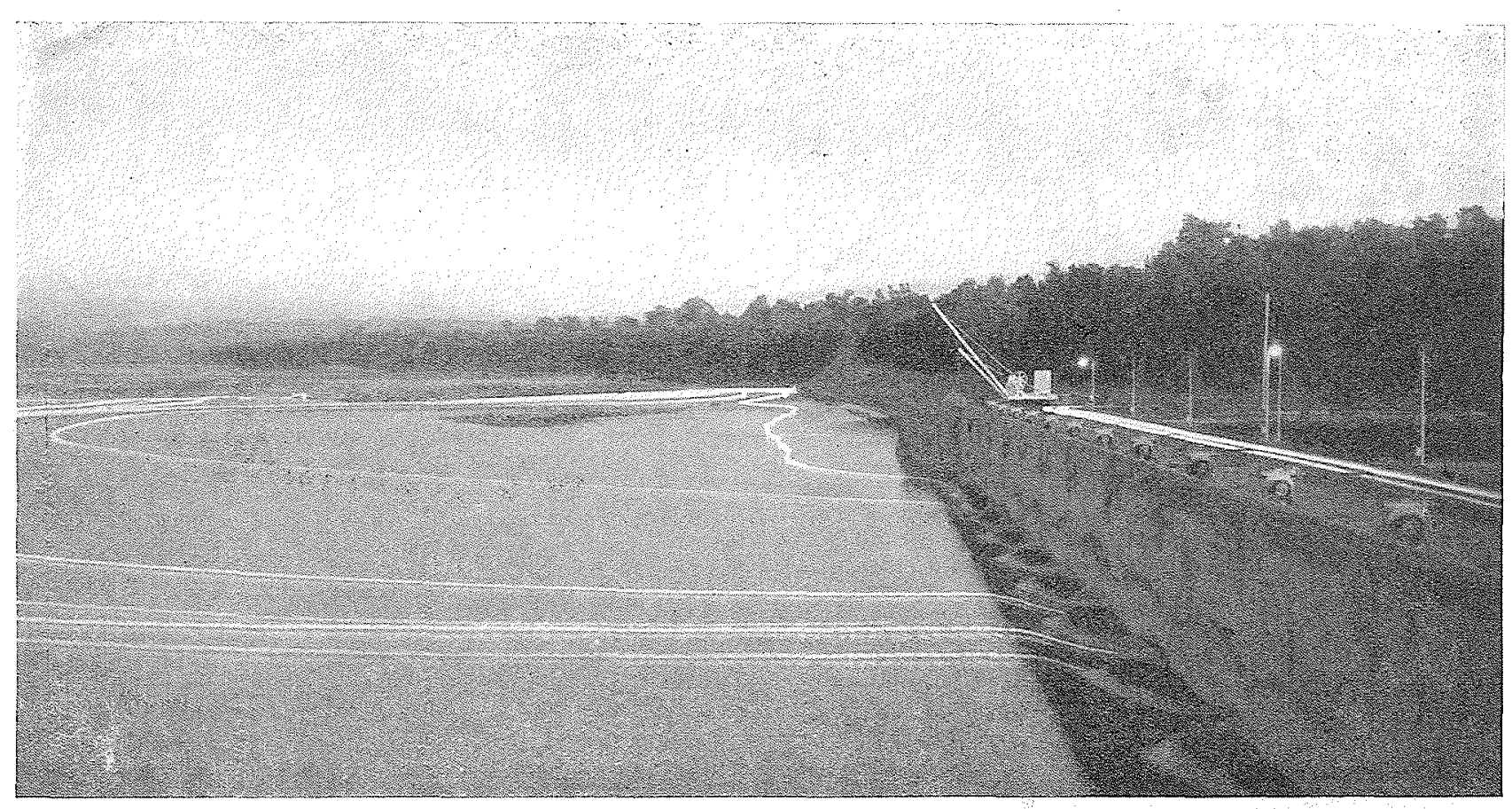

fig. $3 E$

View of River Ravi looking upstream.

It can be seen from the float lines that the no I left bank float travels close to the bank, and, the water being very shallow and the velocity low, its passage is hindered by the river bed, this causing it to take a zigzag course. The following float makes a large loop, but reaches the headworks before float no 1. Four floats are seen to enter intake no 4 , this large number indicating the presence of a deep channel in front of the intake, and confirming conclusions reached during model studies.

Vue vers l'amont de la Ravi.

D'après les lignes faites par les flotteurs, on peut constater que le flotteur de la rive gauche se déplace près de cette rive. L'eau étant peu, profonde et sa vitesse lente, le flotteur s'accroche sur le lit de atteint les qui provoque un mouvement en z!g zag. Le flotteur suivant decrit une large course, mais nombre élevé indique la présence d'un chenal profond en face de l'ouvrage, confirmant ainsi les résultats obtenus sur le modèle réduit.
obenal profond en face de 


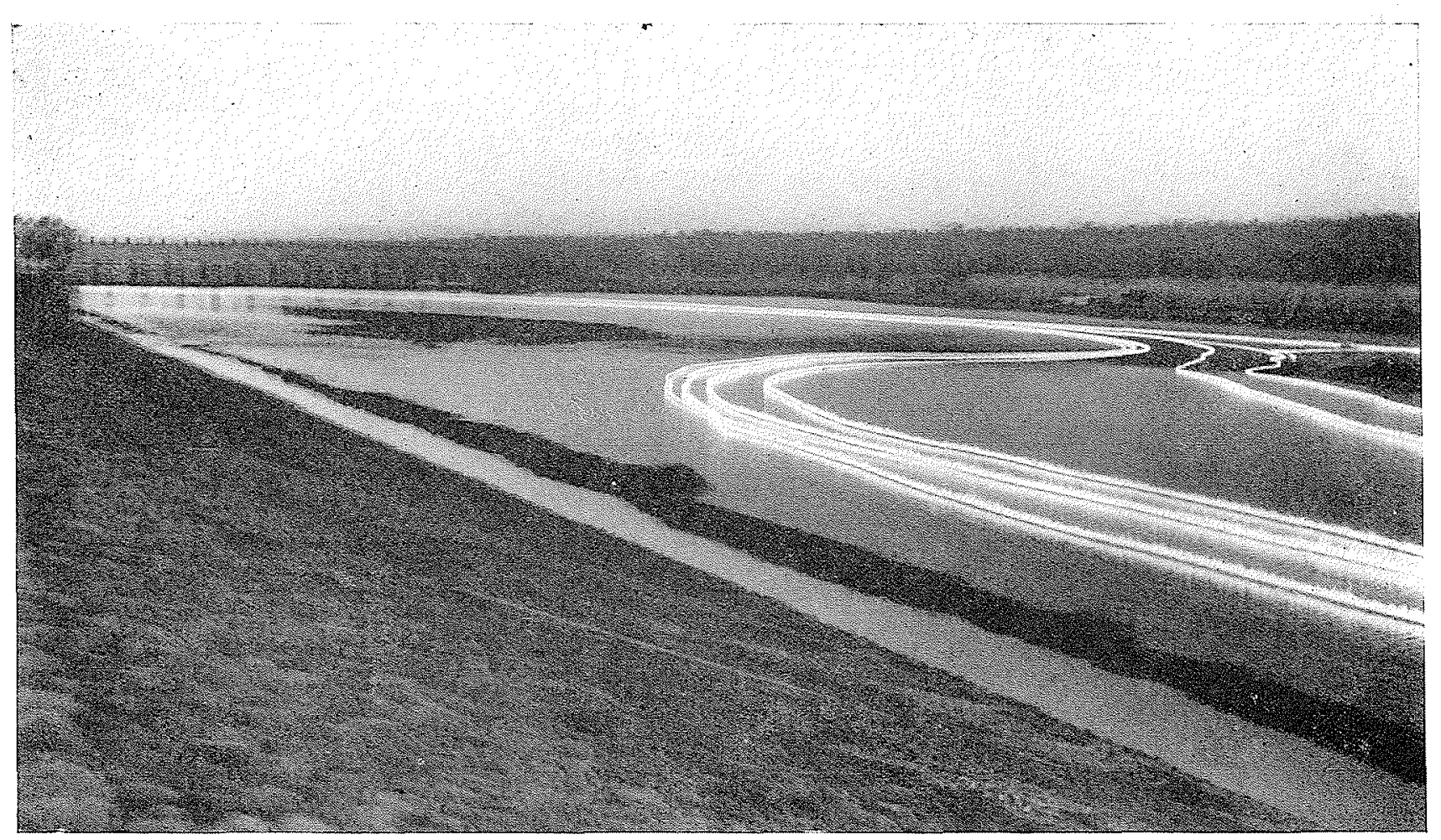

fig. $3 \mathrm{~F}$

Current directions in River Ravi above Madhopur Pocket observed at end of November 1940.

Directions du courant dans la Ravi à l'amont do la retenus de Madhopur, fin novembre 1946

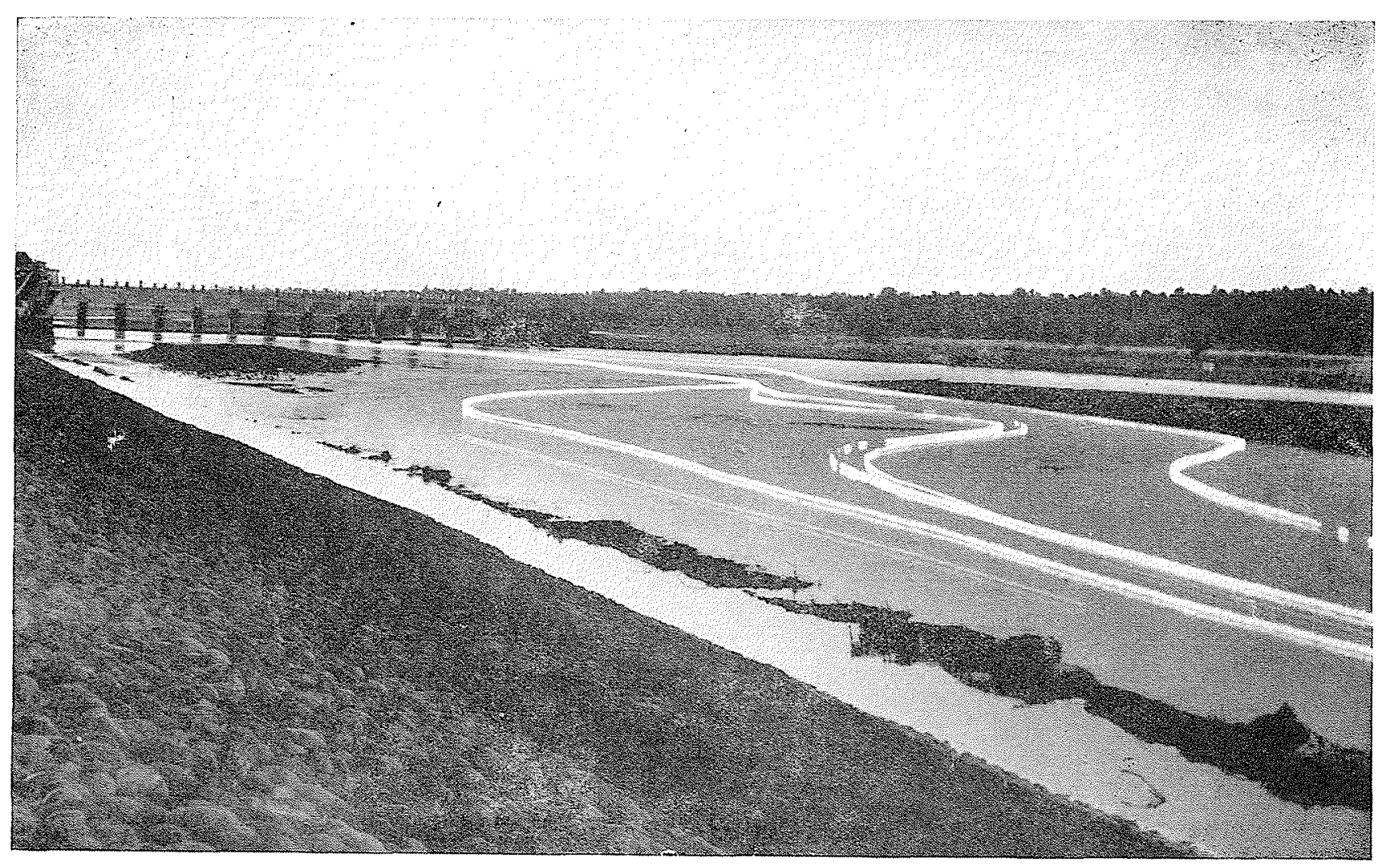

fig. $3 G$

Madhopur Headworks

Current directions in River Ravi observed in November 1940

Ouvrages de prise de Madhopur

Directions du courant dans la Ravi, en novembre 1940 
nant l'entrée des matériaux dans le Upper Bari Doab Canal System.

Sur une portion de son cours près de Western Bein, la Beas érodait gravement sa rive gauche que l'on protégeât, en 1948, par des épis revêtus. Après la construction de ces épis, l'érosion de la berge dans cette zone diminua considérablement et un dépôt apparut le long de la rive. Ceci est bien visible sur la fig. 4. Tous lies flotteurs sont détournés de la rive gauche, par suite de la présence du dépôt près de la berge. direction of flow at several important places on Punjab rivers. For instance

1. River Sutlej upstream of Suleimanke Headworks.

2. River Beas at the armoured spurs.

3. River Ravi upstream of Madhopur Headworks.

7. River Sutlej upstream of Rupar Headworks.

5. River Jumna upstream of Tajewala Headworks

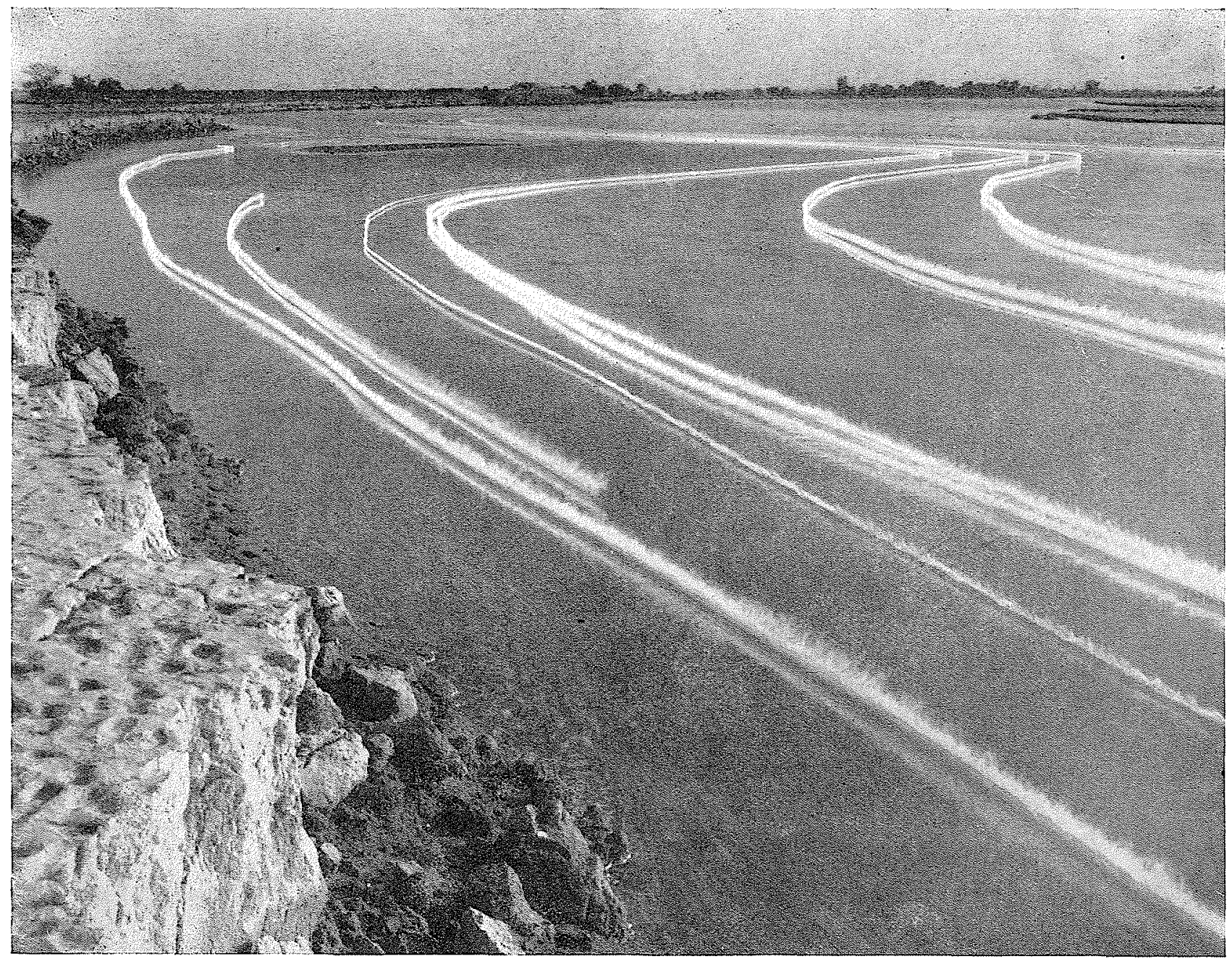

fig. 4

Armoured spurs on River Beas, near Dasuya.

Current directions taken on River Beas, near Dasuya. Armoured spurs were constructed on the left bank which was severely eroded in this reach. As can be seen from the current directions, this is no longer the case. Shoal formation has taken place near the bank, this being indicated by the large detour made by the floats. Some of the floats drift outo the shoal and do not continue.

\section{Epis revêtus sur la Beas, près de Dasuya.}

Directions de courant relevées sur la Beas, près de Dasuya. Des épis revêtus ont été construits sur la rive gauche qui était sérieusement érodée dans cette partie. Comme on peut s'en rendre compte d'après les directions de courant, ce n'est plus le cas. Un depót s'est formé près de la rive, qui est indique par le grand détour que font les flotteurs. Quelques flotteurs se sont échoués sur le haut fond et se 
Au niveau de l'un des trois épis, la largeur débitante de la rivière s'est trouvée considérablement réduite et l'ouvrage est soumis à rude épreuve. Ceci est illustré par la fig. 5 où l'on voit les lignes de courant provenant des différentes parties de la rivière, venir se rassembler vers l'épi. De même la fig. 6 montre le comportement de la rivière à l'approche de l'ouvrage régulateur de tête du Western Jumna Canal.

\section{Lignes de courant dans les canaux.}

Cette méthode s'est avérée, à l'usage, beaucoup plus commode encore pour la détermination des lignes de courant dans des canaux. Les points à partir desquels les flotteurs sont lâchés sont mieux définis et l'on peut se servir d'un bateau en s'attachant, à la rigueur, à un câble métallique tendu au travers du canal.
The current directions on the River Ravi at Madhopur for different months are shown in Fig. 3 (A-G). A lot of valuable information was obtained from these photographs in connection with the silt entry into the Upper Bari Doab Canal system.

A reach of the river Beas near the Western Bein where the river was eroding the left bank very severely was protected by armoured spurs in 1942. With the construction of the spurs the bank erosion in these reaches was considerably reduced and shoals formed along the bank. This is very clearly shown in Fig. 4. All the floats are deflected away from the left bank due to the presence of the nearby shoal.

At one of the three spurs, the whole of the

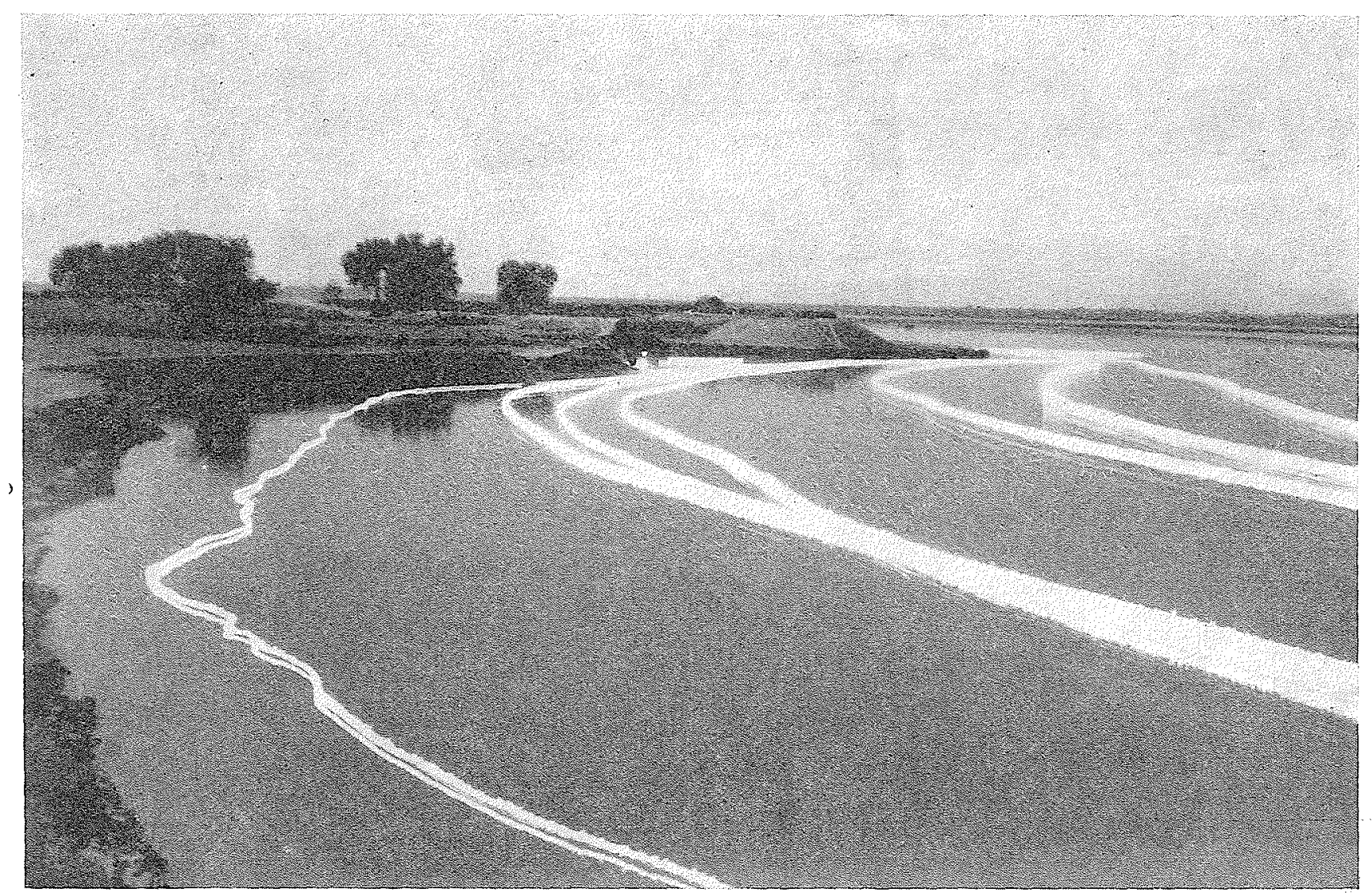

fig. 5

River Beas at third spur.

Current directions show that the whole river is concentrated at the spur. The swirl formation is clearly shown by the lines joining at a point in front of the spur.

La Beas au droit du troisième épi.

Les directions de courant montrent que le débit de la rivière est concentré dans le voisinage de l'épi. La zone tourbillonnaire est nettement définie par les diverses lignes concourrant en un point en face de l'épi. 


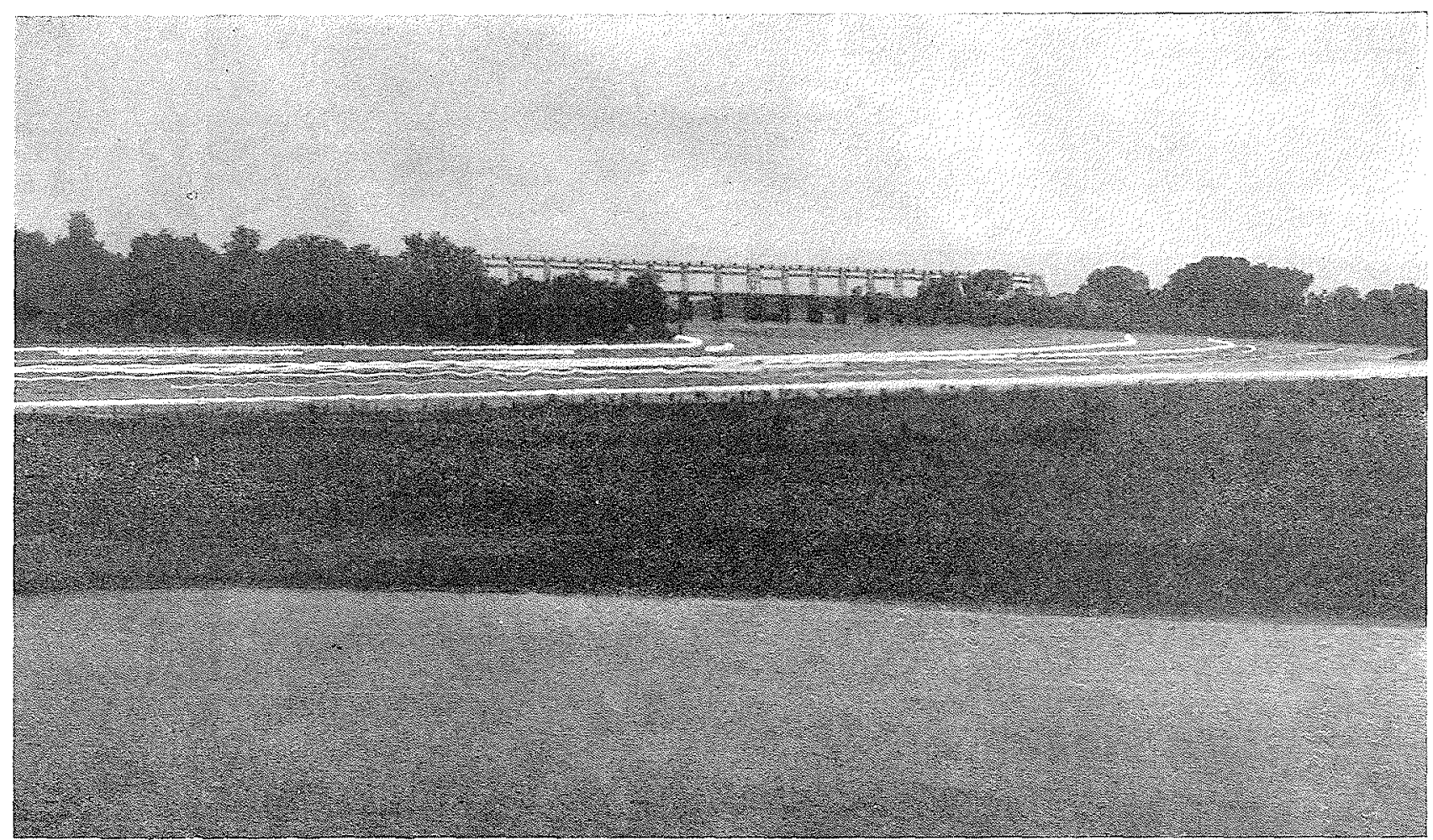

fig. 6

Current directions in pocket at Tajewala headworks

Directions de courant dans la retenue des ouvrages de prise de Tajewala

C'est ainsi que les lignes de courant ont pu être tracées aux stations suivantes:

$1^{n}$ Ouvrage régulateur de prise de Tibri.

$2^{\circ}$ Ouvrage régulateur de prise de Sathiali.

$3^{\circ}$ Ouvrage régulateur de prise d'Aliwal; tous trois rattachés à l'Upper Bari Doab Canal.

$4^{\circ}$ Ouvrage régulateur de prise de Faquirian sur le Lower Ihelum Canal.

Cette méthode est actuellement très largement utilisée dans d'autres stations de recherche des Indes.

\section{Lignes de courant sur les modèles de rivières ef de canaux.}

Cette méthode a été employée avec beaucoup de succès pour la détermination des lignes de courant sur des modèles de rivières et de canaux. Pour cette application, la mise en ceuvre doit être légèrement modifiée. Au lieu d'employer les flotteurs décrits ci-dessus, on introduit dans le modèle une petite plaque de bois sur laquelle on fixe une petite lampe portative munie d'un river became concentrated and very heavy action occurred at this spur. This is shown in Fig. 5 . It will be seen that current directions from different parts of the river strike the spur. Similarly, the river approach to the Western Jumna Canal head regulator and to Tajewala undersluices is shown in Fig. 6.

\section{Current directions in a canal system.}

For taking current directions in a canal system this method has been used with much greater convenience. The points from which the floats are thrown are more definite, and a boat for dropping the floats can be used even from a wire rope stretched across the canal. By this method current directions at the following sites were traced:

1. Tibri Head Regulator, Upper Bari Doab Canal.

2. Sathiali Head Regulator do

3. Aliwal Head Regulator, do

4. Faquirian Head Regulator, Lower Jhelum Canal. 


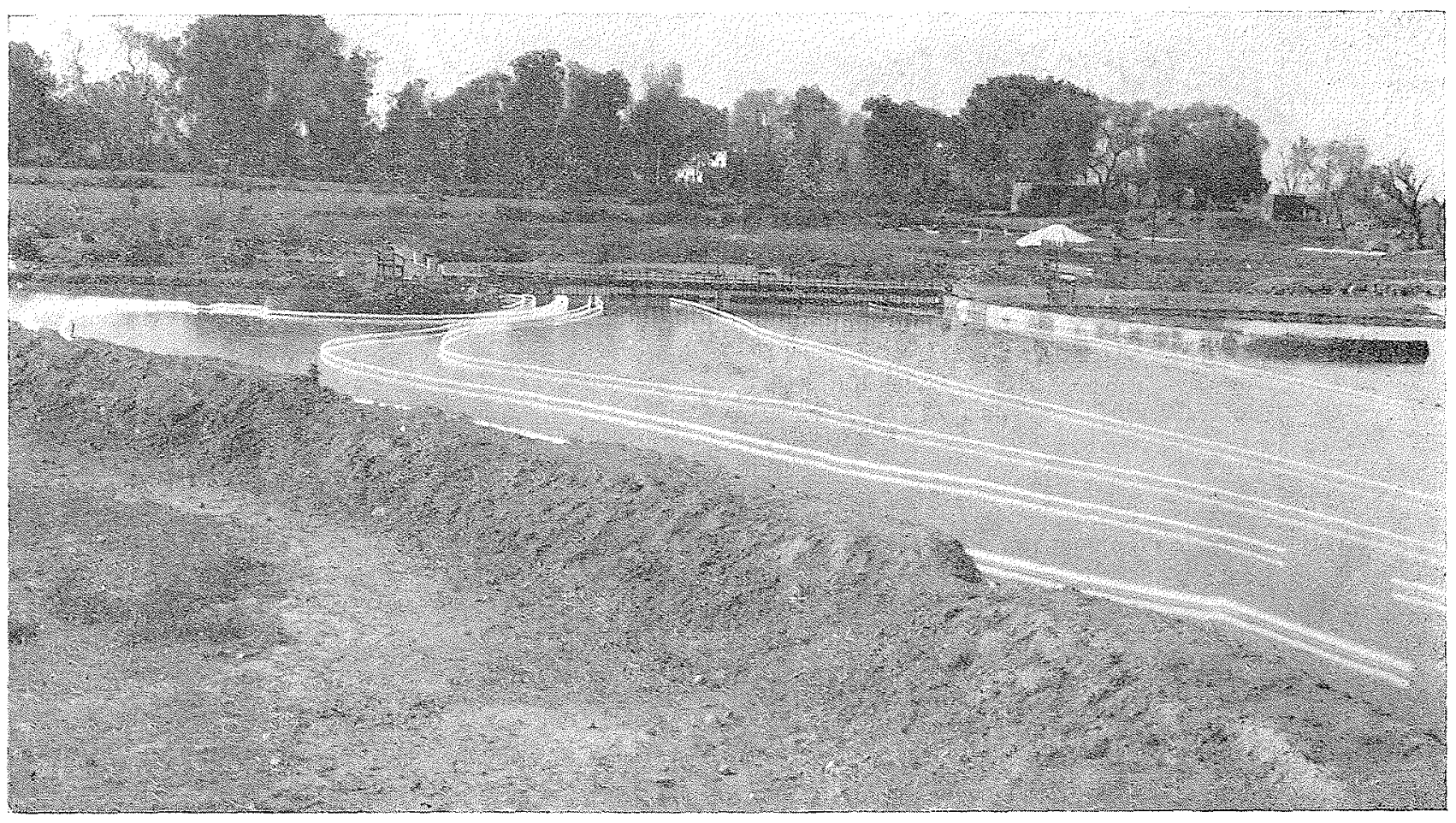

fig. $7 \mathrm{~A}$

River Indus at Kalabagh Headworks

River approach to the weir is being examined with the help of current direction floats. Peculiar river approach from the left side is worth mention

L'Indus aux ouvrages de prise de Kalabagh

Le comportement de la rivière à l'approche du barrage est examiné à l'aide de flotteurs indicateurs de direction. Remarquer tout particulièrement les lignes de courant rive gauche.

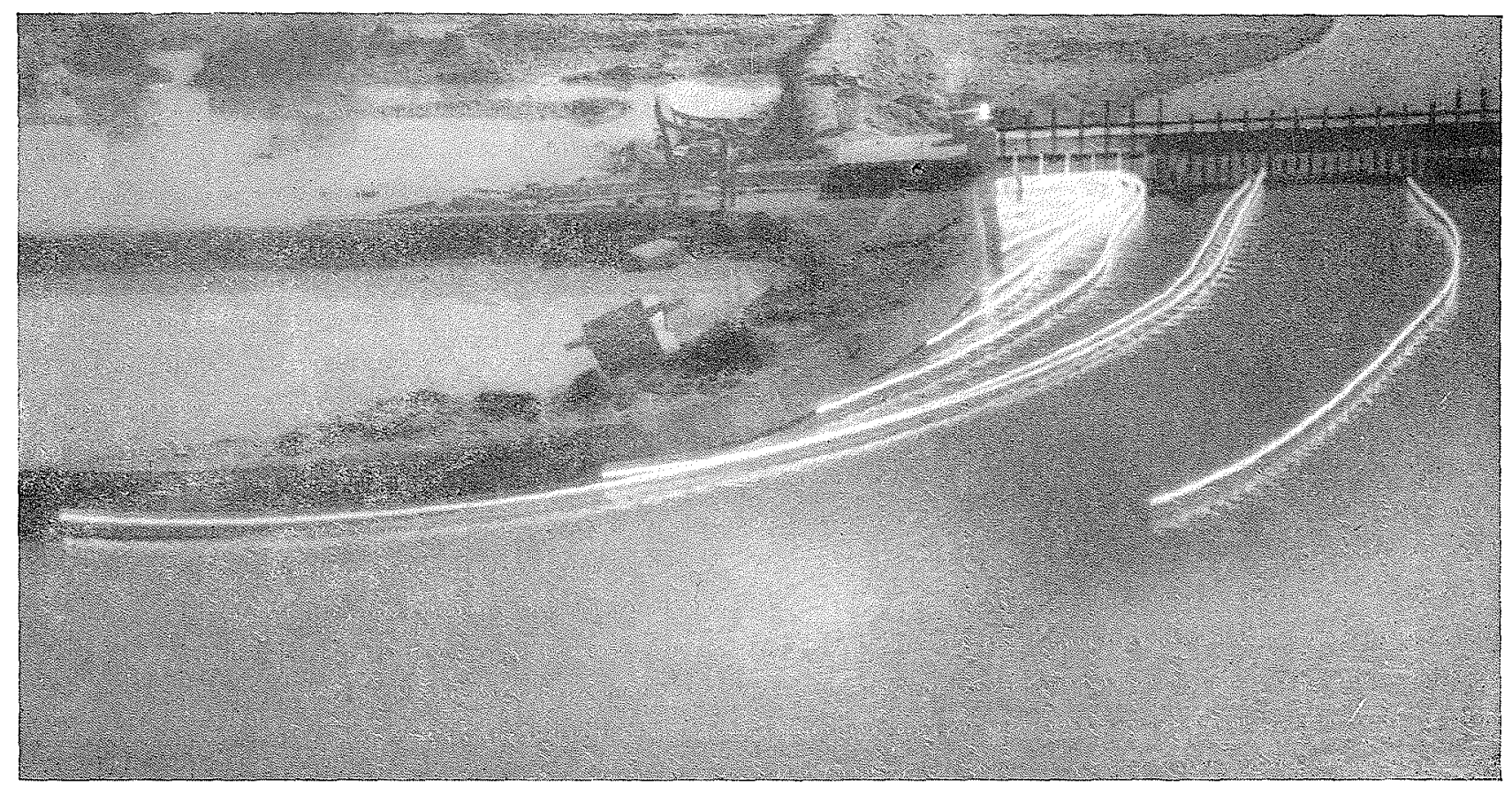

fig. $7 \mathrm{~B}$

Current directions in the left pocket of the Kalabagh Dam with a silt excluder in front of the canal head regulator.

Directions de courant sur la rive gauche de la retenue du barrage de Kalabagh avec un dégraveur en face de l'ouvrage régulateur de tête du canal. 


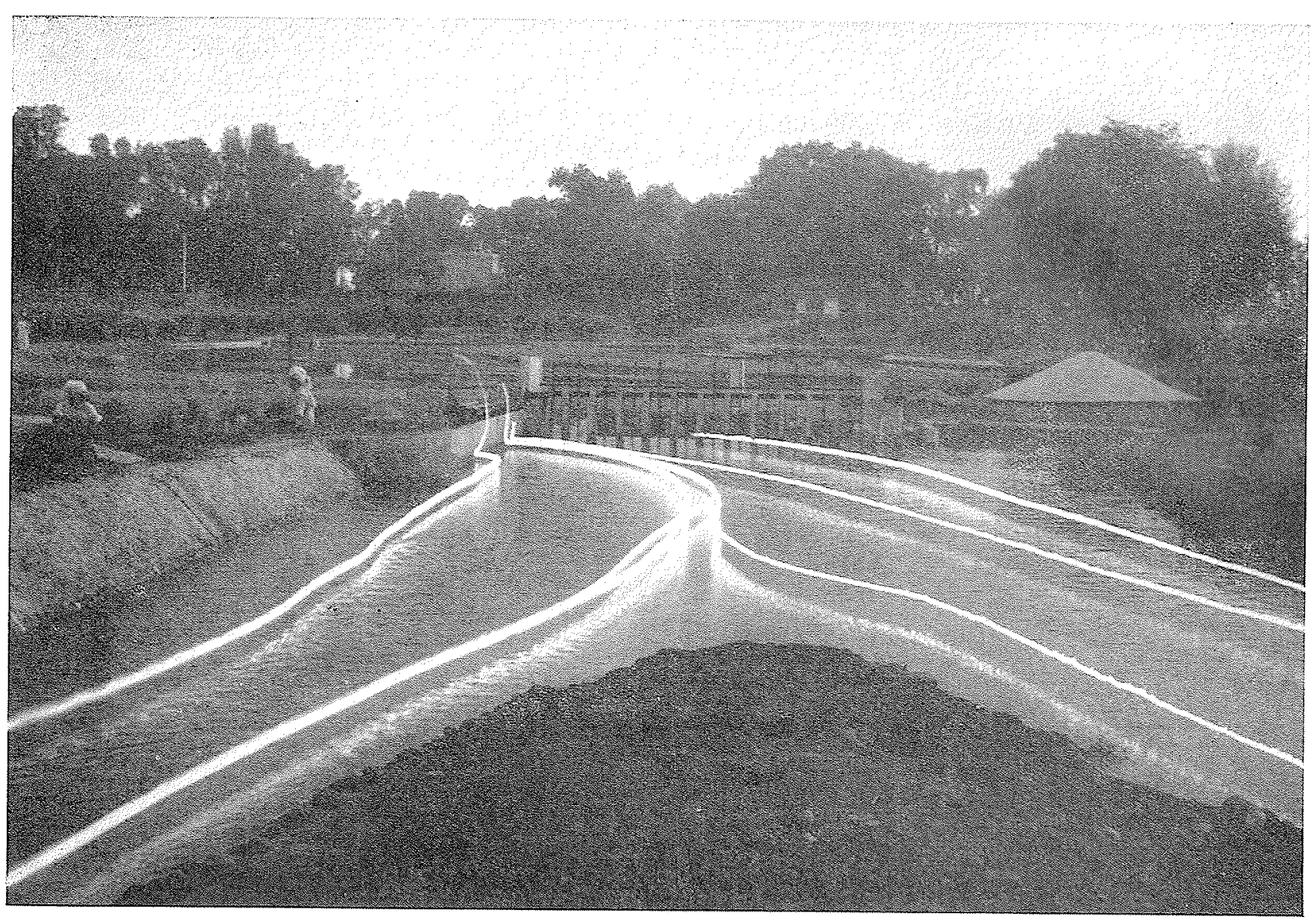

fig. 8

Current directions in River Ravi at Madhopur. September 1940.

Direction du courant dans la Ravi, à Madhopur. Septembre 1940

verre protecteur: Ceci présente l'avantage d'éviter toute extinction de la lumière en dépit du vent ou d'autres facteurs perturbateurs. Pour les petits modèles, on fixe une bougie sur un morceau de liège servant de flotteur ; malheureusement, il arrive à celle-ci de s'éteindre.

Sur les modèles de rivières, il a été fait un usage très considérable de cette méthode.

Ce procédé a permis d'obtenir très nettement les lignes de courant en différents emplacements, comme le montrent les fig. 7 et 8 .

Si l'appareil photographique est muni d'un déclencheur à la demi-seconde, on peut, grâce à ces lignes, déterminer non seulement les directions des courants, mais aussi leur vitesse.

Ce procédé a été mis en œuvre sur les modèles suivants :

$1^{\circ}$ Modèle de l'Indus au niveau des ouvrages de prise de Kalabagh pour la détermination des
This method is now being used extensively at other research stations in India.

\section{Current directions on models of rivers and canals.}

This method has been used very successfully for tracing direction of flow on models of rivers and canal systems. For use on the models the technique is slightly modified. Instead of using large wooden floats as mentioned above, a small table lamp with a glass chimney is fixed onto a small wooden base plate and introduced into the running model. The advantage of the chimney is that inspite of wind or other disturbing factors the light could not be extinguished. In small models a wax candle is fixed onto a cork which serves as a float, the only difficulty being that it sometimes goes out. The method has been used very extensively on river models. By this method sharp lines of flow at different sites are obtained, 
conditions d'écoulement dans la retenue après la Mousson.

$2^{\circ}$ Le modèle de la Ravi à l'amont des ouvrages de prise de Madhopur pour la détermination des conditions d'écoulement dans la retenue après la Mousson.

$3^{\circ}$ Le modèle de la Yumna aux ouvrages de prises de Tajewala.

$4^{\circ}$ Le modèle des ouvrages hydroélectriques de Rasul.

$5^{\circ}$ Le modèle du Pont du Chemin de Fer sur le Western Yumna Canal.

La fig. $7 \mathrm{~A}$ montre le comportement de la rivière à l'approche des ouvrages de prise de Kalabagh tel qu'il a été déterminé sur le modèle à l'aide de ce procédé. La fig. 7 B montre l'effet de la construction d'un ouvrage dégraveur dans la partie rive gauche de la retenue.

La fig. 8 montre l'allure des lignes de courant sur un modèle de la retenue de Madhopur. Les conditions réalisées correspondent au régime de la rivière en septembre 1940 .

Depuis 1941, cette méthode a fait l'objet d'une très large utilisation pour l'obtention, sur les modèles, des lignes de courant de surface.

On a également tenté d'étendre l'application de ce procédé à la détermination des lignes de courant à diverses profondeurs et près du fond : les essais furent couronnés de succès, mais la méthode n'a pas encore été mise définitivement au point.

A l'intérieur du Laboratoire, nous avons, dans certains cas, visualisé les lignes de courant sur le fond et à différentes profondeurs, à l'aide de tétrachlorure de carbone coloré en rouge et avec un mélange, diversement dosé, de tétrachlorure de carbone et de benzine également colorée en rouge Comme colorant, nous nous servons d'un produit local très bon marché et très efficace, appelé Rathan Jot. Pour quelques francs seulement de ce produit, on peut colorer en un très beau rouge 4 à 5 litres de liquide.

Le tétrachlorure de carbone étant plus lourd que l'eau, se déplace sur le fond, tandis que la benzine, plus légère, se déplace à la surface. Suivant le dosage, on obtient des mélanges de densité variable que l'on peut utiliser à diverses profondeurs.

Une fois introduit dans l'eau par l'intermédiaire d'une pipette très fine, le liquide s'égrène en petites gouttelettes.

En 1943, au cours de l'exploitation d'un as shown in Figs. $7 \mathrm{G} 8$. The direction of flow velocity could also be measured from these lines by attaching a half second electric shutter with the camera. The method was used on the following models.

1. River Indus at Kalabagh Headworks for determining the conditions of flow in the pocket after monsoon season.

2. Model of River Ravi above Madhopur Headworks for determining conditions of flow in the pocket after monsoon season.

3. Model of River Yumna at Tajewala Headworks.

4. Model of Rasul Hydro-electric Works.

5. Model of the Railway Crossing on the Western Yumna Canal.

Fig. 7-A shows the river approach to the Kalabagh headworks, determined on the model with the help of this method. Fig. 7-B shows the effect of excluder construction in the left pocket. Fig. 8 shows the current direction on a model of Madhopur pocket in river stages corresponding to September 1940.

Since 1941 the method has been very extensively used on models for obtaining direction of flow at the surface.

Attempts have also been made to apply this method for obtaining direction of flow at different depths and near the bottom. A considerable success has been obtained but the method has not yet been perfected.

In certain cases inside the laboratory, current directions have been traced at the bottom and at different depths with the help of carbon tetrachloride coloured red, and with a mixture of carbon tetrachloride and benzine in different proportions and also coloured red. For colouring the liquid, a very cheap and efficient indigenous vegetable colour, known as Rattan jot, is used. One gallon of liquid can be coloured beautifully red with Rattan lot costing only the equivalent of one cent or half a penny. Carbon tetrachloride being heavier than water moves on the bed, while benzine being lighter than water moves on the surface. Mixtures of different proportions have different densities which can be used at various depths. When introduced into the water 
modèle qui, construit sur un châssis de $3 \mathrm{~m} . \times 2 \mathrm{~m} .50$ et muni d'une glace au fond, représentait l'Indus au niveau des ouvrages de prise de Kalabagh, on put déterminer des lignes de courant grâce à ce mélange de tétrachlorure de carbone et de benzine. Afin de permettre des photographies, l'éclairage était assuré à travers le fond, par des réflecteurs Kodak de grande dimension.

Cette méthode fut employée avec succès sur d'autres modèles également.

L'auteur remercie vivement Mr. T.D. GULHATI M.Sc. son assistant, et le photographe, Mr. SATYA NAND pour leurs intéressantes suggestions et pour l'aide qu'ils lui ont apportée dans la détermination des lignes de courant en différents endroits. through a fine pipette, the liquid is discharged in small drops.

In 1943, in connection with the investigation of a model of river Indus at Kalabagh headworks carried out in a glass bottomed tray $10^{\prime} \times 8^{\prime}$, direction of flow was recorded with the help of tetrachloride and benzine mixture. For obtaining photographs, light was admitted by means of large size Kodak reflectors. This method was used successfully on other models too.

The author is very grateful to Shree T.D. GULHATI, M.Sc., Assistant Research Officer, and Shree SATYA NAND, Photographer, for their valuable suggestions and help in taking current directions at different sites.

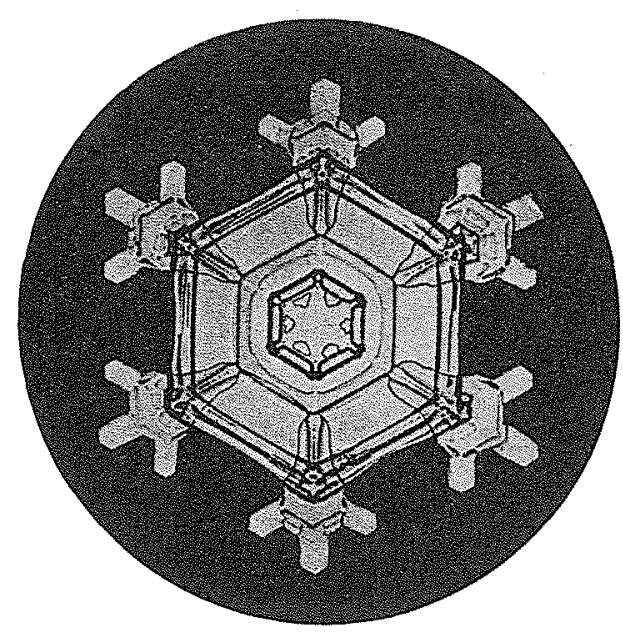

